\title{
The Genie and the Bottle: Reflections on the Fate of the Geneva Protocol in the United States, 1918-1928
}

\author{
Roy MacLeod
}

\begin{abstract}
For Americans serving in the First World War, the advent of chemical weapons made a deep impression. For chemists and soldiers, the experience of meeting - and then making — variants of "poison gas" bred both fear and determination. The wartime creation and post-war struggles of the Chemical Warfare Service reveal the deep divisions these tensions caused, both during the war and through the 1920s, when the United States extensively debated, but failed to ratify, the Geneva Protocol. By the close of the 1920s, the popular optimism that greeted postwar science and invention was clouded by visions of science as a source of new and terrible weapons. In the case of chemical weapons, professional resolve to prepare for future wars competed with a desire to protect the ideals that science represented. In ways that now seem familiar, the profession of chemistry, the chemical industry and the military became powerful allies. This paper examines a subject neglected by historians, and considers how political and professional factors combined to frustrate and delay the early ratification of the Geneva Convention by the United States. As we shall see, our knowledge of these circumstances is far from complete, and will remain so until we have a deeper understanding of the history of America's complex relationship with this toxic legacy.
\end{abstract}

R. MacLeod (ه)

History, University of Sydney, Sydney, Australia

e-mail: roy.macleod@sydney.edu.au

(C) The Author(s) 2017

B. Friedrich et al. (eds.), One Hundred Years of Chemical Warfare: Research,

Deployment, Consequences, DOI 10.1007/978-3-319-51664-6_11 


\section{Introduction ${ }^{1}$}

War is a rough and violent game. Destruction is according to its nature and must be so. Each of the belligerents finds itself in need when facing the foe. And when in need any means are permitted. "Use whatever can be used" is the first law, based on the nature of war -H. L. Gilchrist, 1928.

Thus, Colonel H. L. Gilchrist of the US Army Medical Corps, second chief of the US Chemical Warfare Service (CWS), speaking to the American Chemical Society (ACS) meeting at Chicago in August 1928, almost a decade after the Armistice. Today, the world awaits the resolution of this and many other issues that were left unresolved in 1918 and by the Treaty of Versailles a year later, which together marked what Sellar and Yeatman memorably called "the cause of nowadays" (Sellar and Yeatman 1932). Among these, we must regrettably count the legacy of chemical weapons.

This legacy is today prominent in the Middle East where, in September 2013, the Government of Syria launched a chlorine gas attack on its own population, killing 1,429 people, including 426 children. Since then, the humanitarian tragedy in the Middle East has reached epic proportions. Over 100,000 people have died and the conflict is likely to worsen. Reports of the continued use of chemical weapons reach us almost daily. For over three years, the United States has led in helping to dispose of Syria's declared chemical weapons (CW) stockpile of 1,300 metric tons and to dismantle its $23 \mathrm{CW}$ production facilities, and has overseen (at this writing) the neutralization of 600 metric tons of sarin, VX, and mustard gas - what the US Senate Armed Services Committee has called "the world's worst weapons." 2 But the threat lives on. The United States, with other countries, asks what has become of the vision implicit in the Geneva Protocol of 1925 and its successor, the Chemical Weapons Convention of 1992 (entered into force in 1997), to which 190 statesincluding Syria - have given their assent? What is the future of the norms that these agreements once inspired, in the attempt to put the "Genie back in the Bottle"?

These questions prompt historians to reflect upon the long history of attempts to control the proliferation of chemical weapons. In so doing, however, we seldom recall the factors surrounding the failure of the United States to ratify the Protocol in 1926. Not until January 22, 1975 did President Gerald Ford, following initiatives

${ }^{1}$ I wish to express my thanks to Dieter Hoffmann and Bretislav Friedrich and to Martin Wolf and Jürgen Renn for bringing an Australian from ANZAC Day in Sydney to join this gathering. I wish also to thank the small but influential group of scholars who have studied the history of the Geneva Protocol, including Hugh Slotten, Gilbert Whittemore, Catherine Jefferson, and above all, Julian Perry Robinson and the staff of the Harvard-Sussex Program, in whose archives I have had the pleasure of working.

I dedicate this essay to the memory of Christopher Freeman, founding director of the Science Policy Research Unit at Sussex University, whose experience of war gave him a special appreciation of the Chemical and Biological Weapons Convention.

${ }^{2}$ US Department of State. Protocol for the Prohibition of the Use in War of Asphyxiating, Poisonous or other Gases, and of Bacteriological Methods of Warfare. Signed at Geneva, June 17, 1925, and entered into force February 8, 1928. 
begun a year earlier by President Nixon, sign the instruments of ratification that brought to a close a half-century of discussion. Fifty years earlier, at the Geneva Conference for the Control of the International Trade in Arms, Munitions and Implements of War, the US played a key role in drafting a protocol that was signed by 30 nations, including the US, which prohibited the "use in war of asphyxiating, poisonous or other gases, and of all analogous liquids, materials or devices, as well as the use of bacteriological methods of warfare." But the US Senate declined to ratify the protocol, and without a formal vote.

The historian will ask, why? What were the factors that withheld US Government support for a treaty the origins of which reached back as far as the Declaration of St Petersburg in 1868, the Brussels Declaration of 1874, and the Hague Declaration concerning Asphyxiating Gases of 1899-which the United States also failed to ratify - as well as the Hague Convention on Land Warfare of 1907. These prohibited the use of "poison or poisoned weapons" in warfare, a conclusion on which the leading military powers of Europe found agreement.

Our questioning begins with the American experience of the Great War; with the conception, production, and use of chemical weapons by America; and with the implications of "science mobilized" for American industry, the military, and international relations. The subtext reveals a debate that takes place within a web of conflicting interests, in which the United States, emerging from the war as the world's principal creditor nation, declined to participate in the League of Nations. This essay highlights some questions that surround these issues, the pursuit of which unites historians of science, diplomacy, and economic history who seek to understand America's relationship with this toxic legacy of the twentieth century.

\section{Science and the Great War}

The beginnings of this history are well known. The war began in August 1914 as many had predicted, and soon became a scientific war, for which the Allies were ill prepared. Moral outrage, stirred by the burning of the library at Louvain, the atrocities in Belgium, and the shelling of Rheims, was quickened in October by the "Manifesto of the 93 Intellectuals" (vom Brocke 1985; Ungern-Sternberg 1996; Horne and Kramer 2001).

By November, French scientists were mobilized into munitions work, and by the spring of 1915, Britain had several new research institutions for the War Office and Admiralty (MacLeod 2000, 23-46). The advent of chemical warfare on the Western Front in April 1915 marked a new departure in the application of science to war. The same week that saw the first German use of chlorine gas at Ypres followed by the U-boat sinking of the Lusitania saw the beginnings of a new kind of warfare, with dimensions that have disturbed mankind ever since. By 1918, new weapons, tactics, and technologies contributed to Germany's defeat (MacLeod 2009, 37-51). In an age of modern warfare, chemical weapons had become the "new normal." 
Until April 6, 1917, the United States remained officially neutral, despite the growing participation of large sections of American industry, in which the disciplines of applied science were quick to take advantage (MacLeod 2014). From this experience emerged several significant features of modernity: a powerful scientific establishment, with lobbies that found their way to Congress; the redesign of international scientific organizations along lines favoring American interests; and an increasingly close relationship with the military, in ways that hinted at the militarization of science itself.

Alongside the many wartime applications of science, chemical weapons were to dominate modern memory (MacLeod and Johnson 2006). But Americans came late to gas warfare, and were not its principal victims. US troops saw their first major engagement at Chateau Thierry only in June 1918, by which time gas weaponsand gas defenses - were already used extensively by both sides. Chlorine and phosgene damaged the unwary, but the arrival of mustard gas, new in 1917, devastated American forces on the Western Front, where inexperience and poor discipline contributed to a higher proportion of gas casualties than suffered by Britain, France, or Germany. ${ }^{3}$

Although the US Army struggled, American chemists had been studying and monitoring the use of gas since 1915, when the American Chemical Society mounted a campaign to enlist chemists into the war effort. As the United States began to turn itself into an arsenal for the Allies, the National Academy of Sciences created a National Research Council (NRC) to extend its wartime mandate. In 1917, the NRC responded to the call of its chairman, the astronomer George Ellery Hale: "I really believe this is the greatest chance we ever had to advance research in America" (Wright 1966, 288). America's official entry into the war in April 1917 gave chemical warfare its mandate.

In America's production of chemical weapons, the Bureau of Mines led the way and, by the end of May 1917, had mobilized 118 chemists from 21 university laboratories, three private companies, and three federal agencies to work at Camp American University (still the site of American University) in Washington, D.C. But the War Department had even bigger plans, and, in September 1917, established a Gas Service in the US Army Engineers under General William Sibert. This was modeled on the Service de Chimique of the French Army, and adopted their gas masks and drill. Following the experience of the German offensive in March 1918, the War Department created an autonomous Chemical Warfare Service (CWS), which it tasked with the full spectrum of research, production, and supply. Initially, much of its work was defensive, and an overseas branch was established under General Amos Fries, who later became the Service's director and advocate. Together, Sibert and Fries developed a substantial program of research and development which, at relatively low cost, set out to bring chemistry to America's defense (Fries and West 1921; Fries 1921). Under Sibert, the CWS began by

\footnotetext{
${ }^{3}$ Chemical weapons were said to cost Americans $11 \%$ of their casualties, versus $5 \%$ of the other belligerents. For debate surrounding these figures, see Baxter (2004).
} 

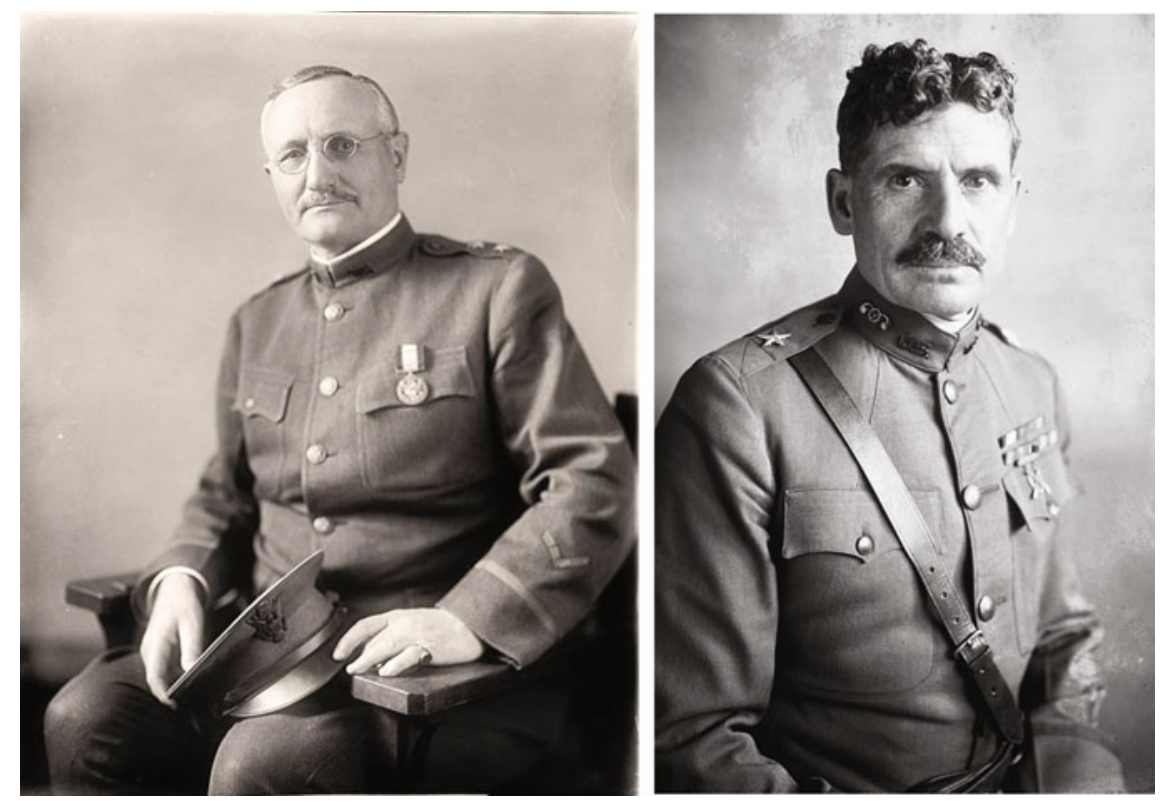

Fig. 1 Left Major General William L. Sibert (1860-1935). Watertown Free Public Library; Right General Amos Alfred Fries (1873-1963). Creative Commons

developing a close relationship with American industry, and especially with the American Chemical Society, and its myriad membership (Fig. 1).

In September 1917, immediately following Germany's first use of mustard, CWS laboratories began to study its method of production; and by March 1918, the research group led by the young Lt. James B. Conant found an efficient process, sharing the credit with Sir William Pope's group at Cambridge, but producing mustard gas before the British (Whittemore 1975, 151; Jones 1980, 426-440). ${ }^{4}$ By the Armistice, America's Edgewood Arsenal was producing 30 tons of mustard gas a day; $35 \%$ of the shells fired by American artillery in France were filled with gas; and the strategists of the United States and Britain, including Benedict Crowell at the War Department and Winston Churchill at the Ministry of Munitions, were anticipating its massive use in the great offensive planned for the Spring of 1919 (Crowell and Wilson 1921; MacLeod and Johnson 2006) (Fig. 2).

With the Armistice, the wartime relationship fostered with industrial and academic chemists continued unimpeded. Many compounds were tested, and new gases were in the offing. The CWS was particularly proud of Lewisite, while the British tested a new arsenical, code-named DA, which was capable of penetrating the most effective German gas masks (Jefferson 2014, 654). The CWS recruited

\footnotetext{
${ }^{4}$ Mustard Gas Warfare: Man who Makes It Tells of Science's Deadliest Weapon and How United States Army Will Use it in Quantities. New York Times, July 7, 1918.
} 
Fig. 2 James Bryant Conant (1893-1978), upon becoming President of Harvard University in 1933. Creative Commons

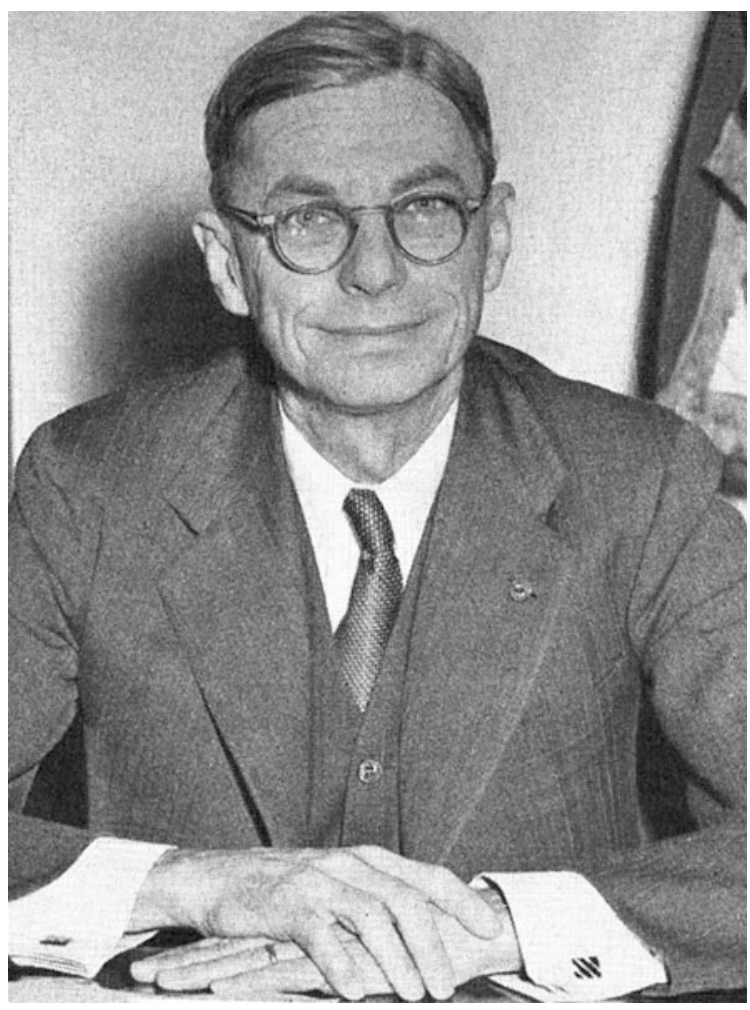

university chemists both to study known problems and to find new problems to solve. The expanding laboratories at Edgewood and Camp American University in Washington, D.C. saw a cross-section of chemists, young and old, academic and industrial (Whittemore 1975, 151). ${ }^{5}$ Before the war, George Burrell, chief of the Research Division at Edgewood, had gone no farther with gases than exterminating small animal pests. Lee Lewis, also at Edgewood, was better known for his work on improving the water quality of public swimming pools (Fig. 3).

Robert Williams, who studied the use of ricin from the castor oil plant, a few grains of which can kill a person, went on after the war to synthesize Vitamin B1 (Whittemore 1975, 152). Others, like Yandell Henderson, professor of physiology at Yale, who developed the first successful American gas mask, wrote on gas warfare and aviation for the Yale Alumni Weekly. Underlying all this effort was the theme of research as "productive scholarship"- the results of which might not appear for years.

\footnotetext{
${ }^{5}$ The work of Gerard Fitzgerald on the wartime Edgewood Arsenal promises fresh revelations.
} 
Fig. 3 Winford Lee Lewis (1878-1943), who invented 'Lewisite.' Wikimedia

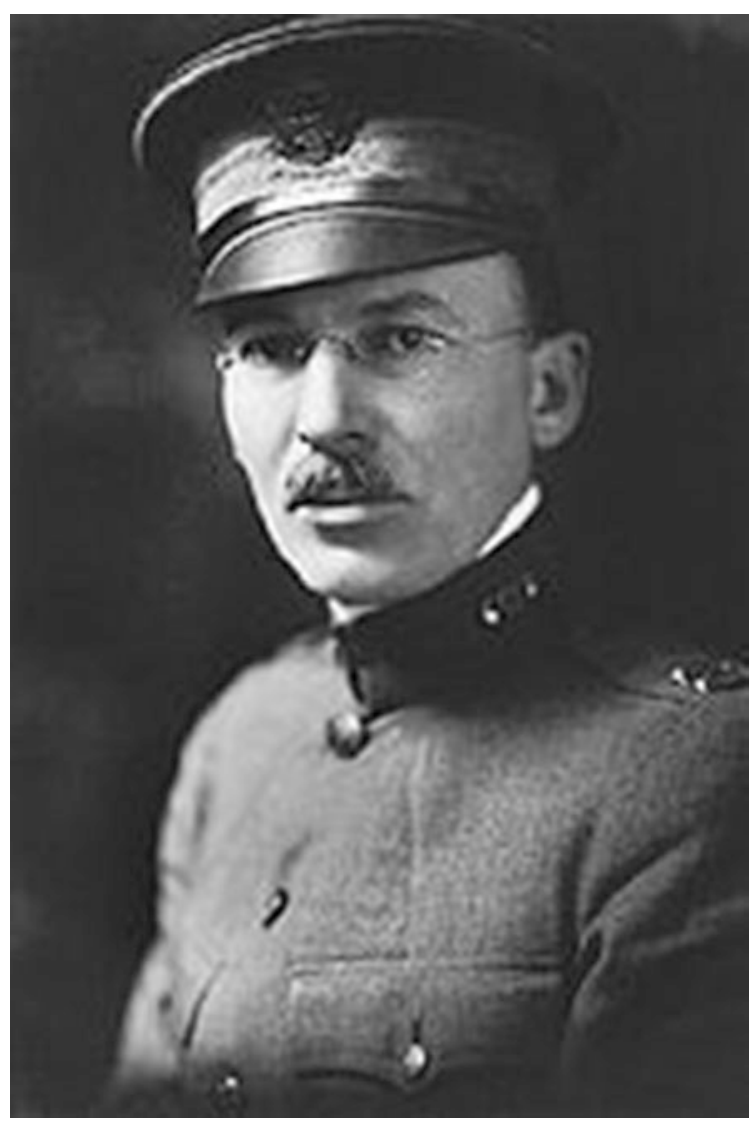

In April 1918, on the third anniversary of the first use of gas on the Western front, Henderson wrote:

We must give the devil his due - the Germans have developed to a high degree the research side of science, and that is what has made it possible for the German army to make this drive $[\ldots]$ and it is by the use of such scholarship [that] we have got to beat those men over there and drive them back (Henderson 1918).

In September 1919, the first postwar meeting of the British Association for the Advancement of Science looked back to the carnage, and appealed to the conscience of the nation: "Science must receive from man its commission to heal the sores that it has made." 6 Similar sentiments were voiced by Woodrow Wilson, speaking at Versailles in January 1919:

\footnotetext{
${ }^{6}$ Science in War and After: Good Angel or Evil Genie. The Sunday Times, September 10, 1919.
} 
We must take, so far as we can, a picture of the world into our minds. Is it not a startling circumstance for one thing that the great discoveries of science, that the quiet study of men in laboratories, that the thoughtful developments which have taken place in quiet lecture rooms, have now been turned to the destruction of civilisation? [...] The enemy whom we have just overcome had at its seats of learning some of the principal centres of scientific study and discovery, and used them in order to make destruction sudden and complete; and only the watchful, continuous cooperation of men can see to it that science, as well as armed men, is kept within the harness of civilization. (Wilson 1919; Schilling 1964)

In the United States, chemists working for the CWS gave the impression that the Armistice had interrupted their work (MacLeod and Johnson 2006). Their experience translated into proposals for government support and was mapped onto the platform of the Progressive Party and onto the program of "preparedness" that helped define interwar America.

\section{The Coming of Geneva}

The Treaty of Versailles, signed in November 1919, affirmed the prewar norm and prohibition of poison gases, in an unvarnished attempt to prevent Germany from again producing, importing, or using chemical weapons. Similar provisions were included in treaties that embraced Austria, Hungary, and Bulgaria. But the issue was too important to leave to noble sentiment. The new League of Nations set out to reach a permanent international agreement. In May 1920, the League's Permanent Advisory Commission on Military, Naval and Air Questions (PAC) ruled that the use of gas was no more cruel than the use of any other weapon and was therefore not amenable to prohibition. But the Council of the League declined to accept this argument and, prompted by reports in England that the CWS had developed aerosols to deliver gas by air, referred the issue back to the Permanent Commission. While experts considered what damage airborne attacks might do to civilian cities, the League was asked to debate an outright ban. ${ }^{8}$

In the early 1920s, American governments were both more and less ambitious in thinking about chemical weapons, largely favoring an international agreement, but anxious lest this entail the loss of strategic and economic advantage. In 1921, the question was brought by the Harding administration to the attention of the Washington Conference on the Limitation of Armaments, a committee of which ruled that it was impossible to limit the use of chemical weapons in war, but that it was possible to forbid their use against non-combatants. When this proposition failed to win supporters, the American delegation, led by Secretary of State Charles Evans Hughes, went further and recommended a total prohibition (Fig. 4).

\footnotetext{
${ }^{7}$ Woodrow Wilson addressing the Second Plenary Session of the Peace Conference, January 1919. US Department of State, Papers Relating to the Foreign Relations of the United States: The Peace Conference, vol. 3, 179. Washington, D.C.: USGPO, 1942-1947. In Schilling (1964).

${ }^{8}$ See The Times, March 15, 1921.
} 


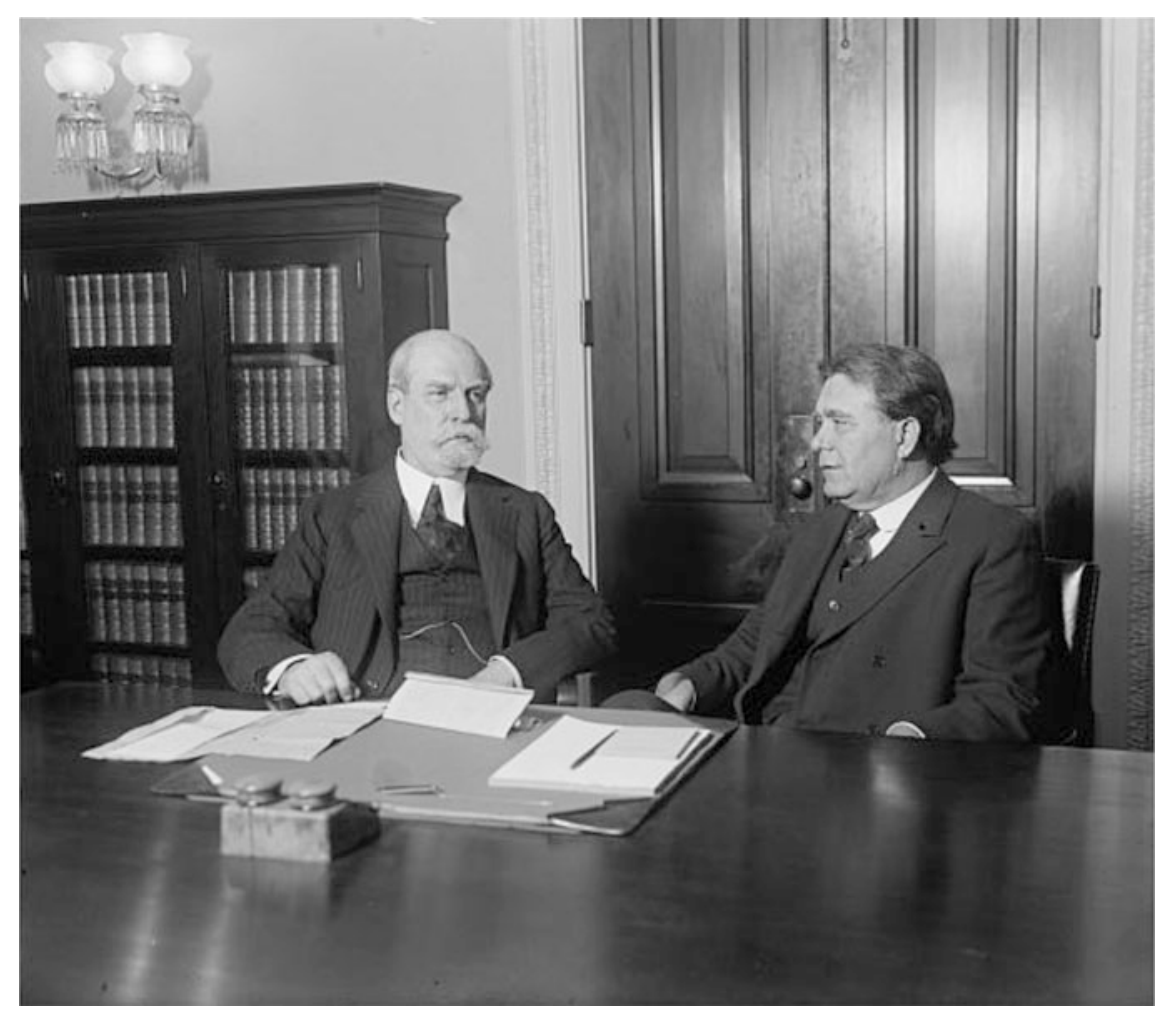

Fig. 4 Left Secretary of State Charles Evans Hughes (1862-1948); Right Chairman of the Senate Committee on Foreign Relations William Borah (1865-1940). Library of Congress

Hughes' view was supported by a national opinion poll, conducted in the United States for the American delegation, which found a majority of Americans in favor of Article V of what became the Washington Naval Treaty, prohibiting the use of chemical weapons "as justly condemned by the general opinion of the civilized world." Signed by the US, the UK, France, Italy, and Japan, this "Five-Power Treaty" was ratified by the US Senate on March 29,1922 by a vote of $72-0$, with 24 abstentions. Only one Senator-James Wadsworth, Jr. (R-NY), chairman of the Senate Committee on Military Affairs-spoke against it. Because the government of France declined to ratify certain provisions concerning submarines, the treaty failed to enter into force. But the idea had gathered momentum, and the United States was seen to have led the way. This is what Daniel Jones has called the "Lesson of 1922" (Jones, 1980, 428).

This lesson was twofold. The first turned on timing. Only seven weeks separated the signing of the Washington Treaty and its ratification by the Senate. Opponents thus had little time to mobilize. The second turned on domestic politics. In this case, 
public opinion had been tested, and found overwhelmingly in favor. Those who opposed had to look for support elsewhere. And this was to come.

For two years, the question slumbered. On September 27, 1924, as Catherine Jefferson has reminded us, the Washington Treaty was brought to the 5th Assembly of the League of Nations, which recommended that a draft convention restricting the use of poison gas be drawn up by its Temporary Mixed Commission on the Reduction of Armaments for submission to member states (Jefferson 2014, 647661). This discussion, of course, excluded the United States, which remained outside the League. However, when the League convened a Conference for the Supervision of the International Trade in Arms and Ammunition and in Implements of War, President Calvin Coolidge authorized a delegation to be sent, led by Rep. Theodore Burton (1851-1929), chairman of the Foreign Affairs Committee of the House of Representatives, which included Herbert Hoover (Secretary of Commerce) and Frank Kellogg (Secretary of State). This conference met in Geneva on May 4, 1925.

Before the meeting, Theodore Burton, who personally supported a ban, persuaded Coolidge that the United States propose to the Conference a provision forbidding international trade in chemical weapons - in effect, a non-proliferation treaty. The Military and Technical Subcommittee of the Conference, to which this proposal was referred, rejected the idea as unworkable on the grounds that it would unfairly discriminate against weaker states that were unable to make weapons on their own. Given this logic, the British, Polish, and Italian delegates proposed to hold a special conference, the purpose of which would be to consider a treaty to ban all chemical and (at the suggestion of Poland) bacteriological weapons. Despite reservations from Italy and Switzerland, their proposal was accepted and a protocol was appended to the final resolution of the Conference. This became known as the Geneva Protocol, which was signed on June 17, 1925.

The Geneva Protocol restated the prohibitions laid down by the Versailles and Washington treaties, with an additional ban on bacteriological weapons. It made no provision for enforcement, nor did it limit the scope of the prohibition. It banned the "use of weapons," but not the weapons themselves. It was effectively a statement of "no first use." Nothing in the protocol specified inspections or sanctions. The protocol did not prohibit development, production, or stockpiling, nor did it provide for a means of verification. But with these limitations, it did confer a measure of legal and moral condemnation of such weapons across the world.

There were, however, many potential flaws in the provision. If, for example, the Great Powers were signatories but Germany and Japan were not, would the protocol be accepted? And what of the United States? In January 1926, President Coolidge sent the protocol to the US Senate for ratification. Coolidge supported arms control, not least because he believed that as peace was the natural ally of an expanding economy, the United States would surely benefit. In any case, the Five-Power Treaty of 1922 that banned the use of chemical weapons among its signatories had sailed through the Senate without a single negative vote. The Protocol would surely have an equally smooth passage. The administration's submission to the Senate 
deleted the controversial submarine clauses and expanded the reach of the ban from five to 41 nations.

This time, however, the government made three fundamental errors. The first was timing. Coolidge signed the Treaty on June 17, but William Borah (R-Idaho), chair of the Senate Foreign Relations Committee and floor manager of the protocol, failed to report the treaty out of committee until a year later, on June 26, 1926. Then, for reasons of timetabling, the debate was not scheduled until December 13, 1926 - almost 18 months after the protocol was first introduced. There was ample time for opposing interests to muster (Fig. 5).

Second, the Senate was poorly briefed. When the protocol finally reached the Senate floor, most Senators remained silent, and only five spoke. The issue was not as pressing as other work before the Congress. Worse still, the White House failed to consult and win the support of the War Department and the Navy (McElroy 1991, 131), both of which were disposed towards the treaty. Without their expert backing, the Senate was obliged to look elsewhere for advice. And into this vacuum leapt Senator Wadsworth, chairman of the Senate Committee on Military Affairs, and a spokesman for the Chemical Warfare Service.

Wadsworth opposed ratification, as he had in 1922, on the grounds of "national preparedness." In 1921, Sir Edward Thorpe had told the British Association for the

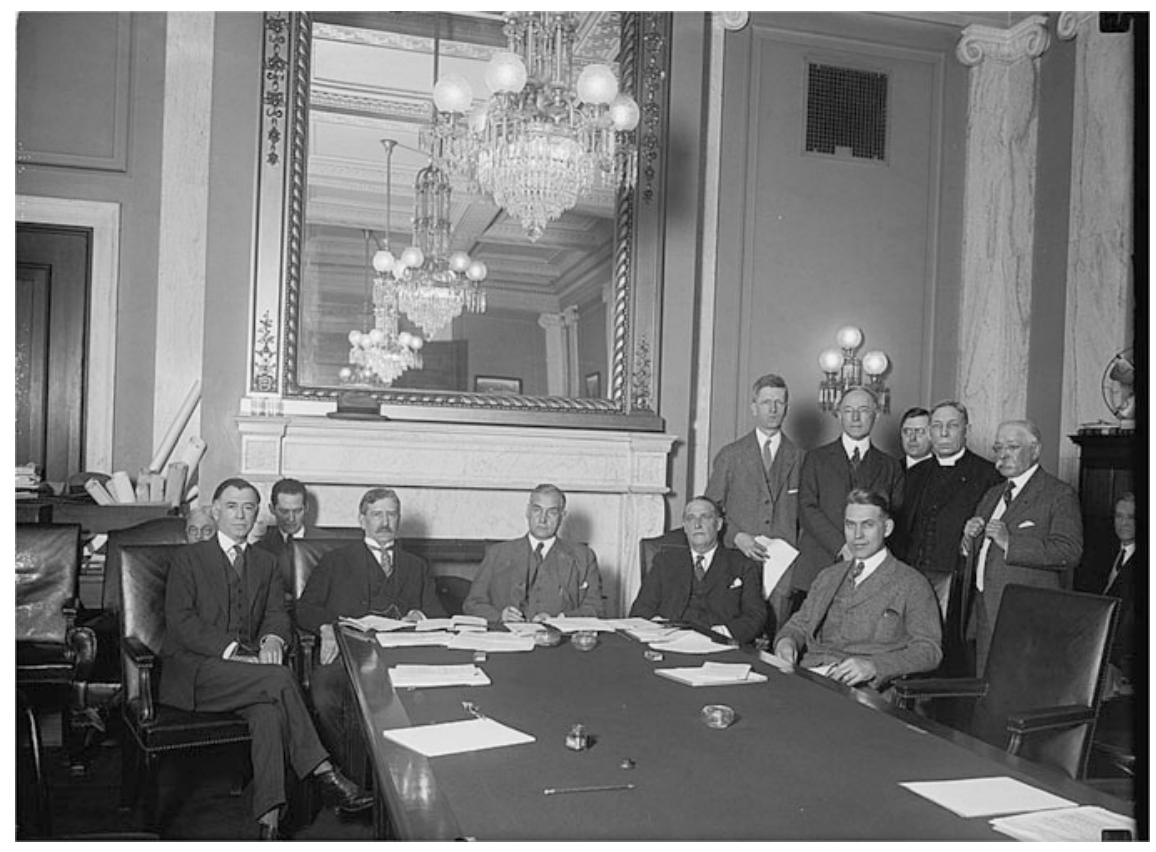

Fig. 5 Senate Foreign Relations Committee, 30 April 1924. Library of Congress 
Advancement of Science that the "moral sense of the civilized world is not so dulled but that, if roused, it can make its influence prevail" (Thorpe 1921). But within the next generation, a trope that Woodrow Wilson had popularized took on a new appeal.

As Frances Harbour has shown, a dozen veterans' organizations were now mobilized, sending petitions that supported "preparedness" and rejected the protocol (Harbour 1990). These factions found influential support from the American Chemical Society (ACS), which in 1925 celebrated its 50th anniversary. The ACS was then the largest chemical society in the nation and one of the largest scientific societies in the world. At least 500 of its members had been in the wartime CWS and were devoted to its survival. The future of the CWS was threatened by the coming of peace. But its leaders refused to go quietly into the night and, throughout the 1920s, marshaled commercial support for its research, with applications ranging from agriculture to perfumery (Faith 2008).

In early 1926, Edgar Fahs Smith, who had been chairman of the Chemical Weapons Subcommittee at the 1922 conference, visited Coolidge and spoke against the protocol. Meanwhile, the ACS lobbied all senators, arguing that "all history shows that any effective weapon available will be used" (Harbour 1990, 13). At its national meeting in Los Angeles in August, the ACS repeated the main arguments that framed its agenda: (1) that chemical weapons were effective; and (2) that gas was a less cruel (or, as often put, "humane") alternative to worse weapons. Echoing the defense advanced in Callinicus by J. B. S. Haldane, FRS, the British polymath (Haldane 1926), ${ }^{9}$ these arguments were buttressed by the campaign for national preparedness, which resisted interference from any foreign power or the League of Nations. Ratification of the protocol, they argued, would force the United States to forego a strategic capability that it had struggled to create (McElroy 1991, 140 150). Secretary of State Kellogg met with representatives of the ACS in November 1926, but failed to secure a compromise.

For months, the question was postponed as the Senate fought over affiliation with the World Court of the League of Nations. Months passed, and it seemed that Kellogg had acquired few allies in the upper house. On December 9, 1926, the first day of debate, the only senator to speak for ratification was William Borah, who quoted General John Pershing:

Chemical warfare should be abolished among nations as abhorrent to civilisation. It is a cruel, unfair and improper use of science. It is fraught with gravest danger to noncombatants and demoralizing to the better instincts of humanity. (McElroy 1991, 132)

\footnotetext{
${ }^{9}$ Haldane's title gave it all away: Callinicus, an eighth-century Syrian prince-his name, of Greek origin, means "beautiful victor"- used "Greek fire" to prolong the survival of the Eastern Roman Empire for 750 years.
} 
The emollient intention of Pershing's words was lost on Senator David Reed (RPenn), who had been an artillery officer during the War:

Are we, then, to go against an inferior antagonist, with all the abundance of artillery that the World War has left us, to blow out of existence a lot of peasants who scarcely know what the war is about? Or are we to take advantage of this great chemical opportunity which we, as a manufacturing nation, have open to us. Would it not be more merciful, assuming that we were at war with some Central American country, to win our battles by the temporary disabling of our enemies than to blow them all over their cactus plants? (McElroy 1991, 141)

After a weekend break, debate resumed, and three other Senators called for rejection. Senator Ransdell (D-La) championed the ACS and the interests of industrial chemistry and expressed the hope that the protocol be "buried so deep it would never appear before us again" (McElroy 1991, 142). At this point, the Administration saw no hope of winning the required two thirds' vote of the Senate. After three days, the State Department withdrew the protocol without putting it to a vote. Contemporaries could have seen this as a strategic retreat-a retreat that lasted for the next 50 years. But Frederick Brown sees the conclusion as almost inevitable, for two compelling arguments. The United States "could not expect to obey agreed restraints unless they were perceived to be in the national interest." To which Senator Wadsworth added: "it is against all human nature to expect a nation to deny to itself the use of a weapon that will save it" (Brown 1968). ${ }^{10}$ The Senate accepted the argument of the CWS that ratification would "stultify if not preclude" readiness for gas warfare; in language which the CWS might have approved, Brown adds, it would be "virtually impossible to allocate scarce resources to increase chemical warfare readiness when the use of gas in war had been prohibited." Preparedness trumped prevention (Fig. 6).

It seems clear that the Senate's de facto rejection of the Geneva Protocol accompanied a shift in American policy away from "in principle" support and towards a precautionary realpolitik. As Frederick Brown put it, "From enthusiastic promotion of any treaty which would reduce the possibility of gas warfare in 1921, the United States had become a rather skeptical bystander by 1931" (Brown 1968, 108-109). The protocol remained in the Senate files until 1947, when the then chairman of the Foreign Relations Committee, Arthur Vandenberg, returned it in response to a pro forma request from the Truman Administration to process unratified treaties. Even then, historians find no reason to suggest that the protocol's retrieval was any more than a housekeeping measure. In a Cold War of rapid movement in secret chemical and biological weapons development, no American president was likely to show an interest in reviving the subject (Harbour 1990, 20).

\footnotetext{
${ }^{10}$ Congressional Record, 69th Congress, 2nd Session LXVIII, Part I, 144-149; cited in Brown 1968, 106-107.
} 

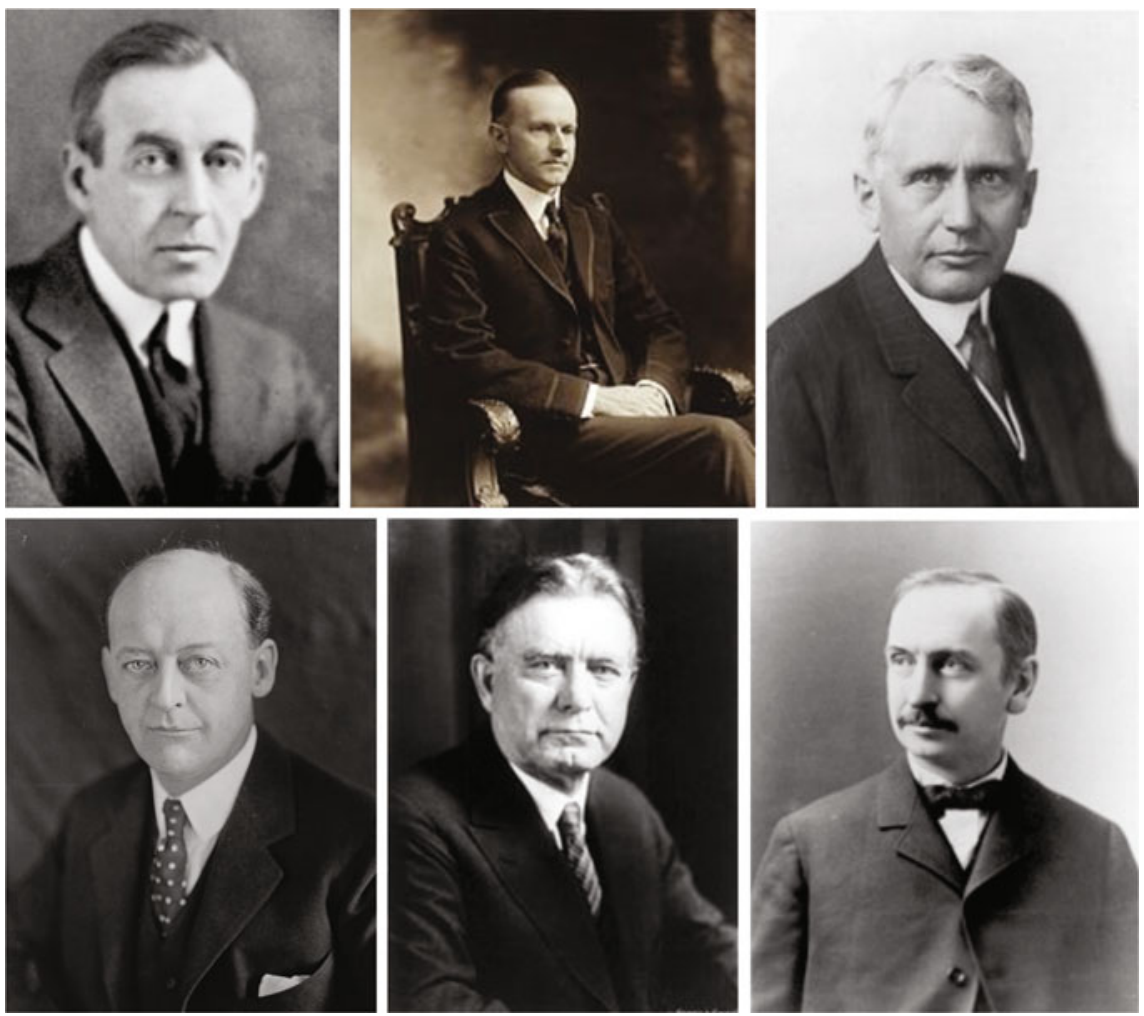

Fig. 6 Clockwise from top left: David A. Reed (1880-1953); Calvin Coolidge (1872-1933); Frank B. Kellogg (1856-1937); Theodore E. Burton (1851-1929); William Borah (1865-1940); James Walcott Wadsworth Jr. (1877-1952). Creative Commons and Library of Congress

\section{A Protocol Post-mortem}

Had the Geneva Protocol, in Frances Harbour's phrase, simply "slipped through the cracks"? Or were other factors at work? How can we best summarize the events of $1926 ?$

Following the successful ratification of the Washington Treaty in 1922, Coolidge seems to have been overconfident of a similarly smooth passage in 1926. Evidently, his confidence was misplaced. More important, the Senate debate, when it finally took place, shows all the effects of intervention by the supporters of the CWS. Although the military establishment never liked the CWS, nor had it won special distinction in the field, the Service had friends in both houses of Congress and in the 
chemical industry, many of whom, it could be argued, had made fortunes from the war and looked forward to a profitable peace.

From the late 1920 s to the early 1930 s, the annual budget of the CWS averaged $\$ 1.2$ million and, in 1934, fell to only $\$ 800,000$ (Baxter 2004, 77). But these modest figures mask the fact that, throughout the 1920s, under Major General Amos Fries (1920-1929), the CWS opened a new chapter in military affairs, testing a range of weapons and acquiring a reputation for innovation. "Medicine and agriculture have been largely benefitted by the evil genie let loose," one sympathetic journalist commented; "From red currants to pumpkins, no fruit has been discovered that cannot be poison-gassed into extra size and nutritiousness," and CWS posters extolled the new dyes that were coming from its war-related research (Slotton 1990, 493). Public disapproval of chemical weapons was broad but not deep, and no one argued against the economic value of research. In any case, with his record of insecticides and perfumes, General Fries could boldly claim he was actually running a Chemical Peace Service (ibid., 492).

A third argument against ratification came from the ACS, which was ambivalent about the implications, if not the intentions, of the protocol. Driven by its wartime experience, the ACS took the side of its chemical colleagues in the CWS, with whom it shared personal and political leanings. In 1918, it was Charles Parsons, Executive Secretary of the ACS and also Chief Chemist of the Bureau of Mines, who with approval reminded the ACS that "War, the destroyer, has been [...] the incentive to marvelous chemical development with a speed of accomplishment incomprehensible in normal times" (Slotton 1990, 486).

The contributions of the war, as George Ellery Hale and the NRC foreshadowed, had already opened to Americans a "New World of Science" (Yerkes 1920). In the wake of the war, the American scientific community had acquired unprecedented recognition and public acceptance. With this also came political accountability of a kind that few had so far mastered. Not only in Germany would professional values be overtaken by patriotism when the national interest made it necessary (MacLeod and Johnson 2002, 169-179).

To the general public, the case advanced by the ACS in 1926 reflected a widely held view that chemical weapons constituted a "humane chemistry," distinguishable from the "scientific barbarism" of conventional weapons. In contrast to high explosives, which accounted for most battle casualties on the Western Front, statistics produced by the British army-widely cited but now contested-suggested that only $3 \%$ of gas casualties died of their injuries, compared with the $40 \%$ of deaths caused by all other weapons. Little was known at the time of the lasting effects of gas, which by Third Ypres in 1917 accounted for 14\% of British casualties (McElroy 1991, 140). 
All weapons were destructive, but some were more destructive than others, and, it was argued, applications of chemistry (and biology) might at least make war endurable. J. B. S. Haldane made what many thought an overwhelming case for gas defense - and also for preventative offence, such as the CWS advocated - on the grounds that it would serve mankind well, not as a means of preventing war, which was impossible, but as a way of making future wars end quicker. Thus, by making warfare more scientific, science would make war more efficient-shorter, simpler, and less damaging to the social order, if not to humankind.

The Geneva Protocol languished in the absence of a strong will to overcome such arguments. But perhaps there was an even deeper reason. In 1921, Will Irwin's highly popular The Next War: An Appeal to Common Sense told the American reading public that the German gas attack in 1915 was as significant as Columbus' discovery of America. As such, it was terrifying. The experience of the War had shown that

Those great and little scientific minds, engaged hitherto in searching for abstract truth or in multiplying the richness of life and the wealth of nations, could be turned toward the invention of means of destruction whether they wished or no. (Irwin 1921, 28)

Irwin cited wartime rumors that a dozen bomb-loads of lewisite could destroy the population of Berlin. If so, poison gas "of a power beyond the dream of a madman, seems to be the killing weapon of the future" (Irwin 1921). The protocol contained no provisions for enforcement. Kellogg said that the United States, in ratifying the protocol, would have to depend upon the "good faith of nations." But why should the United States risk losing the future?

There was also an absence of domestic political pressure. Reportedly, there was less protest in the United States at Germany's first use of gas in France than at the loss of American life on the Lusitania. And when, in 1918, the US Army began to use gas of its own making, there was little domestic opposition. As Hugh Slotten has found, the New York Times surmised that gas had inevitably "been forced upon all the combatants by the custom of the Germans," whilst other newspapers, including the Washington Post, the San Francisco Chronicle and the New York Tribune, did not comment at all (Slotton 1990, 485).

If a majority of Americans were opposed to the use of chemical weapons-and surveys suggested they might be-they were also in favor of being "prepared," which ratification of the Geneva Protocol seemed to override. In the absence of infallible military expertise or domestic political pressure, the floor of the Senate was no place to rally public opinion that had found no great reason to protest. 


\section{Summing up the Senate}

Historians may point to several possible reasons for the US Senate's failure to ratify the Geneva Protocol in 1926. They may include:

1. a lack of strategic planning by the Coolidge Administration, producing a costly delay;

2. an unenthusiastic handling of the protocol on the Senate floor, revealing no coherent strategy for securing ratification; in his annual State of the Union Address, delivered only two days before the Senate debate, President Coolidge failed even to mention the protocol;

3. a failure to mobilize public opinion in support of passage at precisely the time it was needed;

4. a failure to counteract the influence wielded by a confederation led by a Chemical Weapons Service that was fighting for its life;

5. a lack of confidence that the protocol would accomplish its goal; and

6. a failure on the part of the State Department, which neglected to consult with the Army and the Navy.

In the Senate's failure to ratify the protocol, many such factors may have been necessary, but perhaps not sufficient. What surfaces above all else from the Congressional Record is the way in which the protocol suffered from an almost seamless transition from a national narrative of disarmament to a discourse of deterrence. We now see its limitations and imperfections. We accept that the protocol was essentially a no-first-use provision. It prohibited the use of gas, but permitted states to research and reserve the right to retaliate in kind. Even when the US did ratify it in 1975, the protocol did not prohibit development, production, or stockpiling; nor did it specify means of verification. It failed to provide a mechanism for collective response. In this, it illuminated some of the security failures of both the League of Nations and the United Nations (Fig. 7, 8).

To remedy these limitations, the world had to wait for the Chemical Weapons Convention in 1993 (entering into force in 1997), which prohibited the production and use of chemical weapons, provided for the destruction of production facilities (or their monitored conversion to other functions), the destruction of all chemical weapons (including chemical weapons abandoned outside state parties' territory), an inspection regime for the production of chemicals that could be converted to chemical weapons, and international cooperation in the peaceful uses of chemistry. 


\section{SAYS AMERIGA LAGS IN WAR GAS RACE}

Chemical Expert Declares That

Arm of Service Is Treated

Like a Stepchild.

ONE MÀSK TO 100 SOLDIERS

Points to Activity in Germany,

England, Japar and Even in

Latin Republics.

Germany and other European nations, including those of Latin America, are forging ahead in chemical warfare, while the United States is falling behind, according to Dr. Harrison E. Howe, member of the American Chemical Society.

"In this country we have only one rnodern gas mask per hundred enlisted men in the regular army and National Guard," said Dr: Howe, quoting the reported statement that "Germany has stored, ready for use, sufficient modern gas masks to provide five for every soldier authorized by the Treaty of Versailles."

It is plain that "though the ascendency of chemical warfare is written everywhere, the United States Chemical Warfare Service is being treated as a stepchild by those in charge of army appropriations."

Should war come our troops would be required to fight the first six months inadequately protected, said Dr. Howe.

"Italy, shortly after-Mussolini came into power. established a chemical warfare service modeled along the lines of our organization but with: twice the number of officers," he went on. "England appears to be giving chemical warfare the same importance as its three great arms of national defense-Army. Navy and Air Service.

Fig. 7 New York Times, 8 March 1925, p. 26 
“Chemical warfare has been placed under a committee headed alternately by a high ranking officer of the army and a high rankia like England, has placed chemical warfare on the same plane-with other important branches of her service. "Japan has shown great activity along chemical warfare lines, and it is stated that four divisions of troops have been abolished so that the funds thus made available can be spent on the air service and the chemical warfare service.

"Japan has been buying large quantities of chemical warfare supplies from Germany and elsewhere, and is known to be availing herself of: the services of the ablest seientists from the German chemical field.

"France is perhaps as well prepared to use chemical weapons in war as any other nation. though less is known about her plans and actions than any of the other powers. Spain, Switzerland. Poland Czechoslovakia. Sweden. all have chemical warfare service in one form or another, and it will be recalled that Spain used gas against the Moors in one of her campaigns last year. Even Mexico and certain countries in South and Central America are showing a growing interest in chemical warfare.

"Meanwhile, we spend \$1,347,580 to feed the 9,230 horses in the cavalry and at the ration allowed for horses -40 cents per day-the $\mathbf{4} \overline{5}, 000$ horses and mules in the entire army cost $\$ 6.570,000$ for forage alone, not to mention housing, harness, caretakers and replacements.

"There are 122 veterinary officers in the army's latest directory of Jan. 1 , 1925 , and there are 83 officers in the Chemical Warfare Service. The extent to which cavalry has been superseded to which cavaliy has was - well demonstrated by the World War. The ascendency of chemical warfare is written everywhere."

Fig. 7 (continued) 


\section{CHEMISTS DISAGREE ON FUTURR OF WAR}

Inventor of 'Lewisite' Tells Illincis Gathering Gas and Planes Will Dominate.

\section{ARP.'YY MEN SEE LESS CHANGE}

Smoke Screen Demonstration by Airsraft Precedies Statement

That Science Aids Peace.

Special to The New York Times.

UVANSTON, MI., Aug. 18.-Science is the ally of peace, declared Dr. W. Lco Lowis, inventor of "Lowisite," one of the most potent gases used in the World War, tonight at the closing conference of the American Ciremical Society Institute at North western University.

The statement came just after army airplenes had covered the North Shore with a smoke screen in a few minutes as a demonstration of the now technique of warfare and army men had lauded the new a,pllcations of science in developing greater military action.

"If science served warfare only, it would indeed bs a human curse," closed the national defense day program of the institute, cooperating with the National Association of Chemical Defense.

"Even as applied specifically to warfare science makes for peace tecause it gives the balance of power to the more intelligent and advanced race.

Air Strength Not Controllable.

"The tangible instruments of war such as are controllable by agreement will undoubtedly play a smaller part in future warfare than the less tangible. Battleships and fortresses will be less potent agents than airplanes and chemicals.

"The air strength of a nation is not controllable. It depends purely upcn the extent of peace time support of aviation and its commercial ence butwen and a figiting airplane than there is between o merchantman and a battleship.

"A fleet of commercial planes could be converted into bombins planes in a fow hours. There is iittle difference between a peacetime chemical plant and a wartime and procedure are concerned.

.

less addeadly. It is, therefore fund mor nlly an ally of peace. There is little

Êhe Niew Hork Ẽimes

Published: August 19, 1928

Fig. 8 New York Times, 19 August 1928, p. 23 primarlly.

of the joust, the tournament in long ange guns, submarines and poison

Colonel H. L. Gilchrist of the Army nezt war would be one of gas attack

Changes Hard to Foresee Now.

"War at its best," he said, "is a rough and violent game. Destruction is according to its nature and must be so; otherwise, it would not be var. Each of the belligerents finds ts self in need when facing the foe. nnd when in need any means are used" is the "Use whatever can be nature of war. "Just as the world War assumed orms which no man had foreseen in times of peace, no one can today with certainty foretell what form war in the future will take. One thing, however, does seem certain: echnical skill, physics and chemistry Ne used more intensively than ar will play uch being the cose. efense must case. our methods of the ravid strides made in offense", Dr. J. E. Mills, chief chemist of the Chemical IVarfare Service of the army, was inelined to look upon the ossibilities of gas attacks on civilian pulation less seriously.

Gas attacks against a city, it was xplained, can be rendered relatively hinh the following reasons, among 'Gas the lol many Gas cannot travel up wind; any ows closed will shut out and winthe gas for a considerable period of Calls Cold Steel Still Decisive.

Major Gen. Paul B. Malone, who ought at verdun and Chateau Thierry, and is now stationed in the Sixth Corps Area, made the point hat neither air nor gas warfare will liminate or decrease the value of "In view of the possibiluty of transporting airplanes on airplane carriers across the sea, it becomes vident that the defeat of ous fleet pon either ocean will place the suns of a victorious flect within range of our harbors and bring the erritory of an overseas enemy into uxtaposition with our mainland. 列 occssible to "Battles in the

agnitude seercely dreamed ossume a ng the World War, but these battles n the sky will not be decisive. The nfantry and the field artillery, the cavairy. the engineers and all other the service, but slightly affected by this character of warare, will move forth as thev always have in the past to decide the issue " ender more will enter into and war, but machinery will conduct of 作 


\section{Conclusion}

The failure of the US Senate to ratify the Geneva Protocol reflected contrary imaginations and vested interests in the American military, industry, science, and perhaps in public opinion as well. We are accustomed to seeing the protocol as a milestone in the establishment of a diplomatic and moral norm of lasting importance. However, the circumstances of 1925-26 were significant in themselves, having wider consequences that accompanied and foreshadowed deeper conflicts. In particular, we can see-and not just between the lines-evidence of a will to power shown by the natural sciences - the "new bosses of war," as one commentator put it (Slotton 1990, 494). The war had demonstrated a new-found sense of national commitment among American scientists; in the post-war world, the question was how best to "boss" the business of war-related science. Some wanted to keep chemical weapons research under the civilian administration of the Bureau of Mines. But the advantages of a closer connection with the military were clear. The precedent set by the debate would not be lost on those planning atomic weapons research after the Second World War. The protocol debate anticipated by 35 years President Eisenhower's warnings that public policy could become the "captive of a scientific-technological elite" (Jones 1980, 439).

The early 1920s offered reason for both hope and fear-the twin legacies of the Enlightenment. The emerging relationship between science and the military weighed heavily on the conscience of those who, like J.D. Bernal, saw in the outcome of the protocol debate fresh cause to re-examine the politics of science. He and others were inspired to argue that, if science was to have a future, it must show social responsibility - a theme that gained prominence during and after the Great Depression of the 1930s. How rival nations would in future justify their use of the "worst weapon" would take on new definition, and its uses would soon occupy new spaces outside Europe and North America, in Asia, Africa, and the Middle East. But that is another story, for another time.

\section{References}

Baxter, William. 2004. The Chemical Warfare Service of the United States Army during the Inter-War Period. MA Thesis, Texas Tech University.

Brophy, Leo P., Wyndham D. Miles, and Rexmond C. Cochrane. 1988. The Chemical Warfare Service: From Laboratory to Field.In the United States Army in World War II, The Technical Services. Washington, D.C: Center of Military History, United States Army.

Brown, Frederick J. 1968. Chemical Warfare: A Study in Restraints. Princeton: Princeton University Press.

Gilchrist, H. L. 1928. Chemists Disagree on Future of War. New York Times, August 19.

Crowell, Benedict and Robert Forrest Wilson. 1921. The Armies of Industry, I: Our Nation's Manufacture of Munitions for a World in Arms, 1917-1918. New Haven: Yale University Press. 
Faith, Thomas Iain. 2008. Under a Green Sea: The US Chemical Warfare Service, 1917-1929. Ph. D. dissertation, George Washington University.

Fries, Amos A., and Clarence J. West. 1921. Chemical Warfare. New York: McGraw Hill.

Fries, Amos A. 1919, Digital Edition 2013. History of the Chemical Warfare Service in France http://cgsc.contentdm.oclc.org/cdm/ref/collection/p4013coll7/id/886.

Fries, Amos A. 1921. The Future of Poison Gas. Current History 15: 419-422.

Harbour, Frances. 1990. Chemical Arms Control: The United States and the Geneva Protocol of 1925. New York: Carnegie Council on Ethics and International Affairs.

Haldane, J.B.S. 1926. Callinicus: A Defense of Chemical Warfare. London: Routledge.

Hanna, Martha. 1996. The Mobilization of Intellect: French Scholars and Writers during the Great War. Cambridge, MA: Harvard University Press.

Henderson, Yandell. 1918. Gas Warfare and Aviation: The Problems of Productive Scholarship Growing Out of the Present War. Yale Alumni Weekly.

Horne, John, and Alan Kramer. 2001. German Atrocities: A History of Denial. New Haven: Yale University Press.

Irwin, Will. 1921. The Next War: An Appeal to Common Sense. New York: E. P. Dutton.

Jefferson, Catherine. 2014. Origins of the Norm against Chemical Weapons. International Affairs 90 (3): 647-661.

Jones, Daniel P. 1980. American Chemists and the Geneva Protocol. Isis 71 (3): 426-440.

Kevles, Daniel. 1978. The Physicists: The History of a Scientific Community in America. New York: Knopf.

MacLeod, Roy. 2000. Sight and Sound on the Western Front: Surveyors, Scientists and the 'Battlefield Laboratory', 1915-1918. War and Society 18 (1): 23-46.

MacLeod, Roy, and Jeffrey Johnson. 2002. War Work and Scientific Self-Image: Pursuing Comparative Perspectives on German and Allied Scientists in the Great War. In Vom Brocke, Bernhard ed.Wissenschaften und Wissenschaftspolitik: Bestandsaufnahmen zu Formationen, Brüchen und Kontinuitäten im Deutschland des 20 Jahrhunderts. Berlin: Akademie-Verlag, 169-179.

MacLeod, Roy, and Jeffrey Johnson. 2006. The War the Victors Lost: The Dilemmas of Chemical Disarmament, 1919-1926. In Frontline and Factory: Perspectives on the Chemical Industry at War, 1914-1924, ed. Roy MacLeod, and Jeffrey Johnson. Dordrecht: Springer.

MacLeod, Roy. 2009. The Scientists Go to War: Revisiting Precept and Practice, 1914-1919. Journal of War and Culture Studies 2 (1): 37-51.

MacLeod, Roy. 2014. Scientists. In Cambridge History of the First World War, Vol. 2, ed. Jay Winter, 434-459, 704-708. Cambridge: Cambridge University Press.

McElroy, Rodney J. 1991. The Geneva Protocol of 1925. In The Politics of Arms Control Treaty Ratification, eds. Michael Krepon, and Dan Caldwell, 125-166. New York: St Martin's Press.

Russell, Edmund. 2001. War and Nature: Fighting Humans and Insects with Chemicals from World War I to Silent Spring. New York: Cambridge University Press.

Sellar, C., and R.J. Yeatman. 1932. 1066 And All That: A Memorable History of England. London: Methuen.

Schilling, Warner R. 1964. Scientists, Foreign Policy and Politics. In Scientists and National Policy-Making, eds. Robert Gilpin, and Christopher Wright. New York: Columbia University Press; and The American Political Science Review, LVI (2): 287-300.

Slotton, Hugh R. 1990. Humane Chemistry or Scientific Barbarism? American Responses to World War I Poison Gas. Journal of American History 77 (2): 476-498.

Thorpe, Sir Edward. 1921. Presidential Address, Report of the British Association for the Advancement of Science, Edinburgh, 23.

Ungern-Sternberg, Jürgen and Wolfgang von. 1996. Der Aufruf 'An die Kulturwelt': Das Manifest der 93 und die Anfänge der Kriegspropaganda im Ersten Weltkrieg. Stuttgart: Frank Steiner.

Vom Brocke, Bernhard. 1985. 'Wissenschaft und Militarismus: Der Aufruf der 93 An die Kulturwelt und der Zusammenbruch der Internationalen Gelehrtenrepublik im Ersten Weltkrieg'. In Wilamowitz nach 50 Jahren, eds. William M. Calder, Hellmut Flashar, and Theodor Lindken. Darmstadt: Wissenschaftliche Buchgesellschaft. 647-719. 
West, Clarence J. 1920. The Chemical Warfare Service. In The New World of Science: Its Development During the War, ed. Robert M. Yerkes. New York: Century Company.

Whittemore, Gilbert Jr. 1975. Poison Gas Research and the Ideals of American Chemists. Social Studies of Science 5 (2): 135-163.

Wright, Helen. 1966. Explorer of the Universe: A Biography of George Ellery Hale Woodbury. New York: American Institute of Physics.

Yerkes, Robert M. (ed.). 1920. The New World of Science: Its Development during the War. New York: Century Company.

Open Access This chapter is licensed under the terms of the Creative Commons Attribution-NonCommercial 2.5 International License (http://creativecommons.org/licenses/by-nc/ $2.5 /$ ), which permits any noncommercial use, sharing, adaptation, distribution and reproduction in any medium or format, as long as you give appropriate credit to the original author(s) and the source, provide a link to the Creative Commons license and indicate if changes were made.

The images or other third party material in this chapter are included in the chapter's Creative Commons license, unless indicated otherwise in a credit line to the material. If material is not included in the chapter's Creative Commons license and your intended use is not permitted by statutory regulation or exceeds the permitted use, you will need to obtain permission directly from the copyright holder. 